\title{
Front Matter: Volume 10530
}

, "Front Matter: Volume 10530," Proc. SPIE 10530, Ultrafast Phenomena and Nanophotonics XXII, 1053001 (14 May 2018); doi: 10.1117/12.2323282

SPIE. Event: SPIE OPTO, 2018, San Francisco, California, United States 


\section{PROCEEDINGS OF SPIE}

\section{Ultrafast Phenomena and Nanophotonics XXII}

Markus Betz

Abdulhakem Y. Elezzabi

Editors

29-31 January 2018

San Francisco, California, United States

Sponsored and Published by

SPIE 
The papers in this volume were part of the technical conference cited on the cover and title page. Papers were selected and subject to review by the editors and conference program committee. Some conference presentations may not be available for publication. Additional papers and presentation recordings may be available online in the SPIE Digital Library at SPIEDigitalLibrary.org.

The papers reflect the work and thoughts of the authors and are published herein as submitted. The publisher is not responsible for the validity of the information or for any outcomes resulting from reliance thereon.

Please use the following format to cite material from these proceedings:

Author(s), "Title of Paper," in Ultrafast Phenomena and Nanophotonics XXII, edited by Markus Betz, Abdulhakem Y. Elezzabi, Proceedings of SPIE Vol. 10530 (SPIE, Bellingham, WA, 2018) Sevendigit Article CID Number.

ISSN: 0277-786X

ISSN: 1996-756X (electronic)

ISBN: 9781510615458

ISBN: 9781510615465 (electronic)

Published by

SPIE

P.O. Box 10, Bellingham, Washington 98227-0010 USA

Telephone +1 3606763290 (Pacific Time) · Fax +1 3606471445

SPIE.org

Copyright (c) 2018, Society of Photo-Optical Instrumentation Engineers.

Copying of material in this book for internal or personal use, or for the internal or personal use of specific clients, beyond the fair use provisions granted by the U.S. Copyright Law is authorized by SPIE subject to payment of copying fees. The Transactional Reporting Service base fee for this volume is $\$ 18.00$ per article (or portion thereof), which should be paid directly to the Copyright Clearance Center (CCC), 222 Rosewood Drive, Danvers, MA 01923. Payment may also be made electronically through CCC Online at copyright.com. Other copying for republication, resale, advertising or promotion, or any form of systematic or multiple reproduction of any material in this book is prohibited except with permission in writing from the publisher. The CCC fee code is 0277$786 \mathrm{X} / 18 / \$ 18.00$.

Printed in the United States of America.

Publication of record for individual papers is online in the SPIE Digital Library.

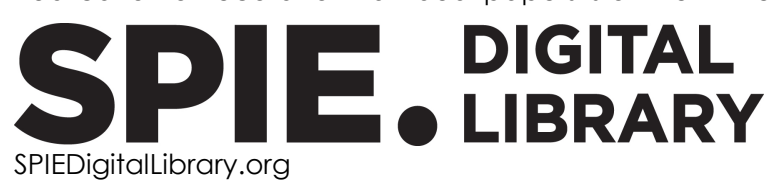

Paper Numbering: Proceedings of SPIE follow an e-First publication model. A unique citation identifier (CID) number is assigned to each article at the time of publication. Utilization of CIDs allows articles to be fully citable as soon as they are published online, and connects the same identifier to all online and print versions of the publication. SPIE uses a seven-digit CID article numbering system structured as follows:

- The first five digits correspond to the SPIE volume number.

- The last two digits indicate publication order within the volume using a Base 36 numbering system employing both numerals and letters. These two-number sets start with 00, 01, 02, 03 , 04, 05, 06, 07, 08, 09, OA, OB ... 0Z, followed by 10-1Z, 20-2Z, etc. The CID Number appears on each page of the manuscript. 


\title{
Contents
}

\author{
$\checkmark$ Authors \\ vii Conference Committee
}

\section{NONLINEAR OPTICS I}

1053003 Giant anisotropic nonlinear optical response in Weyl semimetals (Invited Paper) [10530-2]

1053005 Formation of sub-femtosecond sub-pulses at THG of femtosecond laser pulse [10530-4]

\section{PLASMONICS}

10530 OB Optoelectronic metasurfaces: modulation and detection (Invited Paper) [10530-10]

10530 OC A space-time analysis of electron emission from a focusing structure for surface plasmon polaritons using photoemission microscopy (Invited Paper) [10530-11]

10530 OD Propagation of surface plasmons along low-dimensional materials (Invited Paper) [10530-12]

$10530 \mathrm{OE} \quad$ Using resistive readout to probe ultrafast dynamics of a plasmonic sensor [10530-13]

ULTRAFAST NANOPHOTONICS

10530 OG Coherent optical spectroscopy of charged exciton complexes in semiconductor nanostructures (Invited Paper) [10530-15]

PHONON DYNAMICS

10530 ON Coherent phonon dynamics in misfit-layered chalcogenide LaVS 3 crystal (Invited Paper) [10530-22]

NONLINEAR OPTICS II

10530 OQ Ultrafast zero-bias photocurrent in GeS nanosheets (Invited Paper) [10530-25] 
10530 OT Towards femtosecond electronics based on single-walled carbon nanotubes (Invited Paper) [10530-28]

10530 OV Ultrafast orbital manipulation and Mott physics in multi-band correlated materials (Invited Paper) [10530-30]

10530 OX Femtosecond pump-probe study of negative electron affinity GaAs/AIGaAs photocathodes [10530-32]

\section{GRAPHENE AND ORGANIC THIN FILMS}

$105300 Z$ Landau-Zener-Stückelberg interferometer on attosecond timescales in graphene (Invited Paper) [10530-34]

1053012 Laser-assisted field emission in single-walled carbon nanotubes [10530-37]

\section{TRANSITION METAL DICHALCOGENIDES}

1053015 Optical spectroscopy of interlayer excitons in TMDC heterostructures: exciton dynamics, interactions, and giant valley-selective magnetic splitting (Invited Paper) [10530-40]

1053016 Valley-selective photon-dressed states in transition metal dichalcogenides (Invited Paper) [10530-41]

POSTER SESSION

1053018 Subwavelength imaging and control of ultrafast optical near field in nanosized bowtie and ring [10530-44]

$105301 \mathrm{~A}$ Observing the sub-femtosecond dynamics of plasmonic Bragg reflectors by time-resolved photoemission electron microscopy [10530-49] 


\title{
Authors
}

Numbers in the index correspond to the last two digits of the seven-digit citation identifier (CID) article numbering system used in Proceedings of SPIE. The first five digits reflect the volume number. Base 36 numbering is employed for the last two digits and indicates the order of articles within the volume. Numbers start with 00, 01, 02, 03, 04, 05, 06, 07, 08, 09, 0A, 0B...0Z, followed by 10-1Z, 20-2Z, etc.

\author{
Akimov, llya A., OG \\ Analytis, James, 03 \\ Ballotin, Mariana V., 15 \\ Banfi, Francesco, OV \\ Bas, Derek A., 12 \\ Bayer, Manfred, OG \\ Berini, Pierre, OB \\ Boschetto, D., ON \\ Capone, Massimo, OV \\ Cario, L., ON \\ Cartwright, Alexander, $\mathrm{OE}$ \\ Chen, Borui, OE \\ Chen, Liang, $\mathrm{OX}$ \\ Chen, Yen-Jung, 16 \\ Cheney, Alec, OE \\ Chernikov, Alexey, 15 \\ Christianen, Peter C. M., 15 \\ Cilento, Federico, OV \\ Damascelli, Andrea, OV \\ Dreher, Pascal, 0C, IA \\ Duan, Lingze, $0 \mathrm{X}$ \\ Fabrizio, Michele, OV \\ Fanfarillo, Laura, OV \\ Faure, J., ON \\ Ferrini, Gabriele, OV \\ Fitzgerald, Patrick, $O Q$ \\ Franceschini, Paolo, OV \\ Galle, G., ON \\ Gengler, Jamie, 12 \\ Giannetti, Claudio, OV \\ Green, Mark, 12 \\ Headrick, Robert, 12 \\ Heide, Christian, $\mathrm{OZ}$ \\ Her, Tsing-Hua, 12 \\ Higuchi, Takuya, $\mathrm{OZ}$ \\ Holleitner, A. W., OT \\ Homm, Pía, OV \\ Hommelhoff, Peter, $\mathrm{OZ}$ \\ Huber, Rupert, 15 \\ Jani, Hemang, $\mathrm{OX}$ \\ Janoschka, David, 0C, IA \\ Ji, Boyu, 18 \\ Kang, Ji-Hun, OD \\ Karczewski, Grzegorz, OG \\ Karnetzky, C., OT \\ Kono, Junichiro, 12 \\ Korn, Tobias, 15 \\ Koski, Kristie J., OQ \\ Kushnir, Kateryna, $0 Q$
}

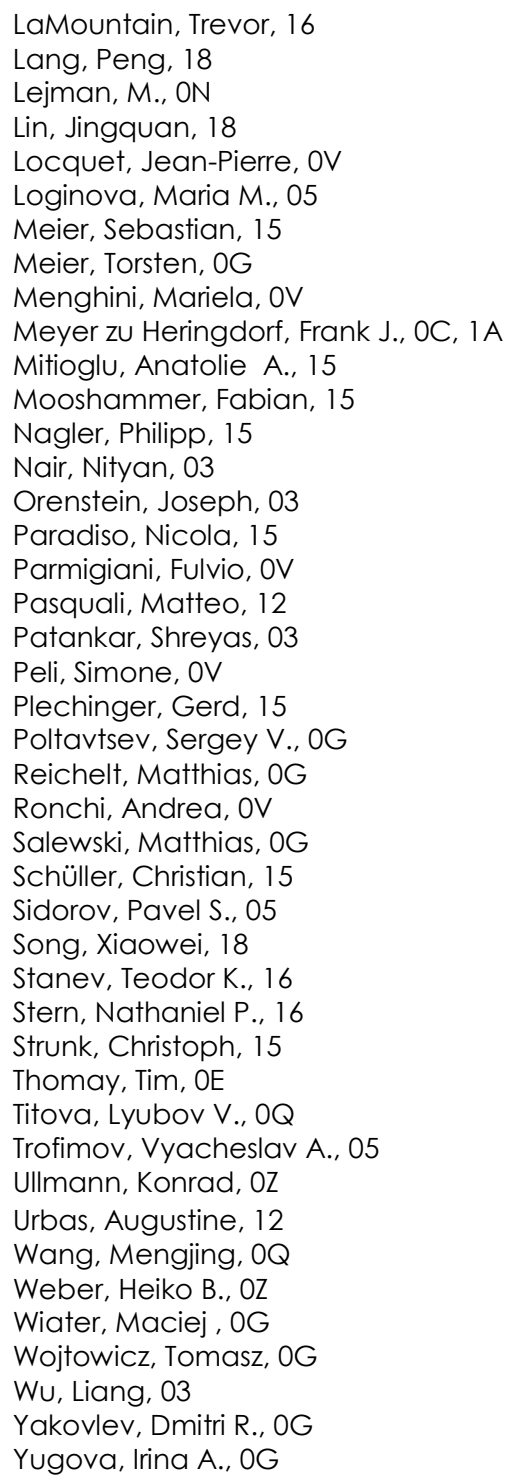


Proc. of SPIE Vol. $105301053001-6$

Downloaded From: https://www.spiedigitallibrary.org/conference-proceedings-of-spie on 26 Apr 2023 Terms of Use: https://www.spiedigitallibrary.org/terms-of-use 


\title{
Conference Committee
}

\author{
Symposium Chairs
}

Connie J. Chang-Hasnain, University of California, Berkeley (United States)

Graham T. Reed, Optoelectronics Research Centre, University of Southampton (United Kingdom)

Symposium Co-Chairs

Jean-Emmanuel Broquin, IMEP-LAHC (France)

Shibin Jiang, AdValue Photonics, Inc. (United States)

Program Track Chair

James G. Grote, Air Force Research Laboratory (United States)

Conference Chairs

Markus Betz, Technische Universität Dortmund (Germany)

Abdulhakem Y. Elezzabi, University of Alberta (Canada)

Conference Program Committee

Alan D. Bristow, West Virginia University (United States)

Kazuhiko Hirakawa, The University of Tokyo (Japan)

Rupert Huber, Universität Regensburg (Germany)

Robert A. Kaindl, Lawrence Berkeley National Laboratory

(United States)

Dai-Sik Kim, Seoul National University (Korea, Republic of)

Xiaoqin Li, The University of Texas at Austin (United States)

Christoph Lienau, Carl von Ossietzky University Oldenburg (Germany)

Torsten Meier, Universität Paderborn (Germany)

Walter Pfeiffer, Universität Bielefeld (Germany)

Pascal Ruello, Université du Maine (France)

Volker J. Sorger, The George Washington University (United States)

Fabrice Vallee, Université Claude Bernard Lyon 1 (France)

Session Chairs

$1 \quad$ Nonlinear Optics I

Alan Bristow, West Virginia University (United States) 
2 Novel Methods in Ultrafast Spectroscopy

Abdulhakem Y. Elezzabi, University of Alberta (Canada)

3 Plasmonics

Nir Rotenberg, Niels Bohr Institute (Denmark)

$4 \quad$ Ultrafast Nanophotonics

Frank J. Meyer zu Heringdorf, Universität Duisburg-Essen (Germany)

5 Phonon Dynamics

llya Akimov, Technische Universität Dortmund (Germany)

6 Nonlinear Optics II

Volker J. Sorger, The George Washington University (United States)

7 Ultrafast Carrier Dynamics

Lyubov V. Titova, Worcester Polytechnic Institute (United States)

8 Graphene and Organic Thin Films

Alexander Holleitner, Technische Universität München (Germany)

9 Transition Metal Dichalcogenides

Alan D. Bristow, West Virginia University (United States) 